\title{
Social and Economic Activity of the Elder Generation in Tomsk Region
}

\author{
Veronika A. Malanina ${ }^{a}$, Elena A. Frolova ${ }^{\mathrm{b} *}, \mathrm{Hu}_{\mathrm{Le}}{ }^{\mathrm{c}}$ \\ * Corresponding author: Elena A. Frolova, fea78@tpu.ru \\ ${ }^{a}$ National Research Tomsk Polytechnic University, 634050, Lenina av., 30, Tomsk, Russia
}

\begin{abstract}
http://dx.doi.org/10.15405/epsbs.2017.01.29

Social and economic activity of the Russian elder generation has a contradictory nature. On the one hand, Russian pensioners often continue working beyond the existing comparatively low retirement age, on the other hand, in terms of involvement in volunteering, political activities, and even in care for children and grandchildren they lag significantly behind the average European level. Explaining it only by the lack of time does not seem plausible, since in many European countries, the employment rates, involvement in unpaid work and caring for other family members are all higher than in Russia. In our study we attempt to identify reasons for lower social and economic activity of older adults in Russia as compared with European countries. We use data of Tomsk regional survey $(2015, \mathrm{~N}=400)$ for accessing older adults' social activity. Data analysis on Tomsk region suggests that employment (as an activity) and education (as a prerequisite) contribute to higher involvement in social interactions in later life.
\end{abstract}

(C) 2017 Published by Future Academy www.FutureAcademy.org.uk

Keywords: Older people; active ageing; life satisfaction; employment; trust; Tomsk region.

\section{Introduction}

Predictors of level and content of socio-economic activity of the older generation are related to the influence of the two main groups of factors: the objective conditions of life of older people, for which they are often unable to exert any significant influence (Taran, Anikina, \& Ivankina, 2016) and subjective preferences, which affect the behavior of older people in the community (Frolova, \& Malanina, 2016). Economic activity is typically finds its realization in the following aspects of the older generations' life: employment, consumption, savings (Kolev, \& Pascal, 2002), production in subsistence farming (Tchernina, \& Tchernin, 2002). 


\section{Social and economic activity of older adults in Russia}

If we analyze the employment of the elderly population by age groups, it is possible to note the relatively low employment of Russians aged 55-59 years (average for Russia it is 59.9\%), while many European countries - Sweden, United Kingdom, Finland, the Netherlands, Estonia, Germany, Czech Republic, Denmark - have employment rate in this age segment over 70\% (Fig.1).

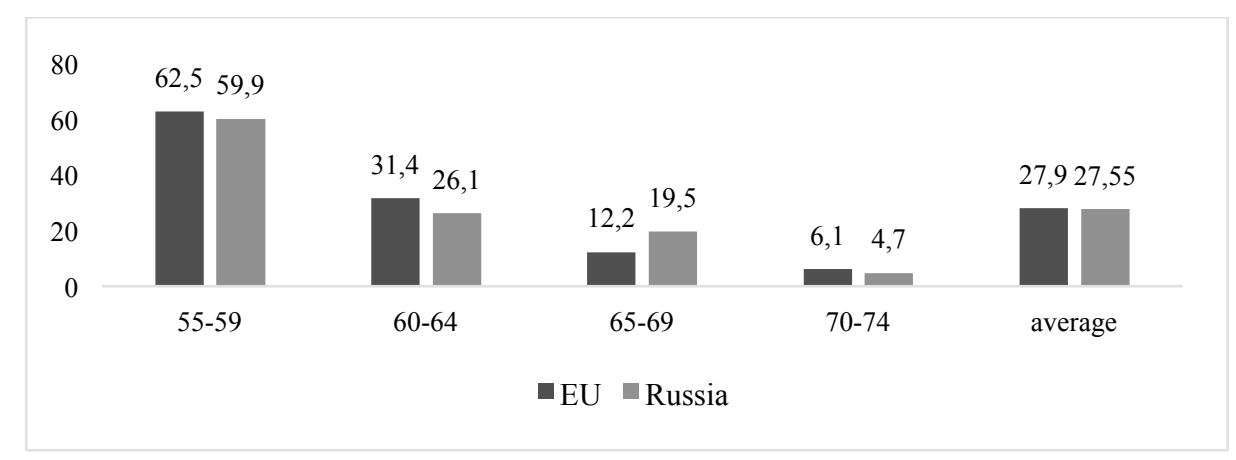

Fig. 1. Older adults' employment (\%) in the EU and Russia by age groups (Zaidi, A., \& Stanton, .D. (2015); Elder generation (2015)).

The low employment of older people in the age group from 55 to 59 years in Russia is explained, above all, by the institutional conditions. The current pension system provides the opportunity for women to retire at 55 years, respectively, we observe fall in employment among older women from this age in Russia. Although there is no formal age discrimination in the labor market, informal norms, based on the perception of older people as insufficiently stable workers in terms of health and the probability of retirement at any time, complicates labor relations of pre-retirement and retirement age individuals.

At the age segment of 60-64 years the employment of older people in Russia is also slightly behind the average European, and in addition to the reasons mentioned above, there are other reasons for decline - men enter the retirement age, for the citizens employed as civil servants effective age restrictions come into force.

In the segment of 65-69 years the employment of Russian pensioners appears over 7 percentage points higher than in Europe, which can be caused by unsatisfactory experience of leaving the labor market, entering the retirement age hoping to live on pension only, and being forced to search for parttime work. This hypothesis is confirmed by a survey of older people in the Tomsk region, who say that money is the main and dominant motive for continued employment (84\%) (Tomsk survey, 2015, $\mathrm{N}=400$ ).

Opinion polls, revealing the opinion of Russians show that $75 \%$ of respondents (and $73 \%$ of citizens older than 60 years) consider a continuation of the work after the retirement age as a need to make a living, rather than a free choice (Press release, 2015). Thus, retirement is not a reason to give up working. The relatively high employment of older people in Russia in comparison with European countries caused by income deficiency that also finds support in the framework of sociological research in the Tomsk region ( $41 \%$ of respondents reported that they have enough money only for food, and $1.8 \%$ of respondents reported that money is not enough even for food). In the age segment over 70 
http://dx.doi.org/10.15405/epsbs.2017.01.29

eISSN: 2357-1330 / Corresponding Author: Elena A. Frolova

Selection and peer-review under responsibility of the Organizing Committee of the conference

years we have seen a sharp decline in employment for various reasons - the institutional side of the labor market and personal, related to the reduction of opportunities of health.

Analyzing consumption as a component of economic activity, on the basis of sociological research in Tomsk region, we can confirm that retirees experiencing financial difficulties (about 43 percent of those surveyed buy only food), reduce the consumption in comparison with the period of labor activity. The share of respondents who were forced to economize on various goods and services is high (24$41 \%$ ). Economizing can occur as a result of the reduction of claims, due to the substitution of purchased food products by products grown in subsistence farming, or as a transition to products of lower quality and Giffen goods. Due to reduction of income, older people may face the reduce in energy value of the food and nutrition and thus reducing physical activity. The transition to a lowcalorie (but not necessarily cheaper) food can be observed due to health problems. Low diversification of consumption may be dictated by the habits and mistrust to new foods. The savings on the purchase of new clothes and shoes for elderly is feasible in practice, since there is a possibility of substitution of new products by available stocks, there is no need to follow the fashion, and there is no reason for the conspicuous consumption, especially for non-working pensioners and rural residents.

Savings as a component of economic activity in the Russian pensioners are at a low level. An urgent problem is the low level of financial literacy, lack of confidence in financial institutions, the relatively low level of income does not allow for savings in principle. Only $22 \%$ of citizens older than 60 years are willing to spend all revenues received for current needs without putting anything in reserve. However, part of the income of pensioners not spent in the current period is still not converted into assets - they can not invest in real estate or make other major purchases, also bank accounts and deposits are less trusted by Russian older generation.

Thus, in terms of the economic activity of the elderly population, we can say that Russia is at the European average employment level (excluding shadow employment and self-employment), but at the same time the employment is rather forced, and is dictated by the low income of the age group. On the part of consumption and savings Russian pensioners have limited activity because they do not have sufficient resources, mistrust financial institutions and intermediaries offering services in investment savings. Surveys show that the importance of subsistence farming in the revenues of Russian pensioners is traditionally exaggerated, still, farming is often an integral component of activity and lifestyle.

On the basis of AAI methodology (Zaidi, \& al., 2013), we also compared the level of social activity in Russia and European countries, considering such forms of social activities like volunteer work, caring for children and grandchildren, caring for elderly persons and political activity. The level of social activity in Russia is quite low in all sub-domains, even helping children and grandchildren in comparison with some European countries is low, in spite of the traditional concept of Russian families as multigenerational and actively caring for the younger and older generations.

Russia ranks last in Europe on average for participation in society. For this situation there are some objective reasons: the weak development of social activity of the infrastructure (volunteer organizations are scarce - no more than $7 \%$ of all non-profit organizations in Russia, and not always 
presented in the rural areas), low level of public awareness about the social projects, ageism, health problems.

The survey of elderly respondents in Tomsk and Tomsk region also revealed low social activity of older people. As previously noted, the participation of older individuals in public organizations in the sample is small and ranges from $1 \%$ involved in the activities of political parties to a maximum of $8.5 \%$ of participation in other organizations, including unions, subsistence farming associations, community councils, garage cooperatives. Political activity in the form of participation in demonstrations, protests, meetings with political leaders on a regular basis is negligibly small - up to $1 \%$ of the respondents, number of people who take part in such an activity from time to time does not exceed 5\%. Accordingly, people demonstrate their willingness to participate in such public organizations in which they will have direct access to important economic decisions and put these decisions into practice in relatively small groups.

There are a number of subjective reasons for low social activity: the low level of general trust (25.3\%) and institutionalized trust (a relatively high level of confidence is demonstrated only in respect of the President and the army). However, productive participation in society requires a high level of confidence in the regional and local authorities, whose management failures are likely to become more apparent to the respondents. That trust determines the stability of the socio-economic system, provides the coordination of interests of various economic actors. It is generally recognized that the high level of confidence stimulates economic and social well-being of the population.

According to the results of sociological research in Tomsk region it is possible to note a rather low level of general trust. Those who are inclined to trust others, are mostly women with an income between 6 and 12 thousand rubles per month, and men with incomes from 13 to 18 thousand rubles per month (39.8\% of all respondents who trust others). Considering trust in terms of the place of living, we observe close relationship between the place of residence of the respondent and the level of interpersonal trust. The more inclined to trust are women, who live in the city of Tomsk and Tomsk region. The least trusting are men who live in rural areas, which is counterintuitive with conventional notions of community character of life in rural areas, there people are believed to have a higher level of trust, due to closer ties between members of the community, as opposed to the urban settlements with large population and, as a result, weaker social ties, requires additional institutional framework for relationships and interactions. Higher levels of interpersonal trust found among the elders who live in urban areas, due to the following factors: the presence of stable social contacts outside the family and friends (continuous employment), and higher education level. Additionally, we need to assess the impact of marital status and age of the respondent.

The dependence of the level of trust and the level of education, found in Tomsk study confirms the findings made earlier by Russian and foreign scientists: a higher level of interpersonal trust is common for individuals who have professional training. This is due to the presence of common cultural and professional competence, social capital, formed in an educational institution, and throughout the employment period. It is also possible to observe gender differences in the level of interpersonal trust among the respondents: men traditionally have less trust in others than women. 
http://dx.doi.org/10.15405/epsbs.2017.01.29

eISSN: 2357-1330 / Corresponding Author: Elena A. Frolova

Selection and peer-review under responsibility of the Organizing Committee of the conference

All this affects the overall life satisfaction of elderly people in Tomsk region. Among respondents satisfied with their lives, the city dwellers, on average, are more satisfied with life than people in rural areas and small towns in the region (Fig. 2). This fact is directly related to the level of interpersonal trust.

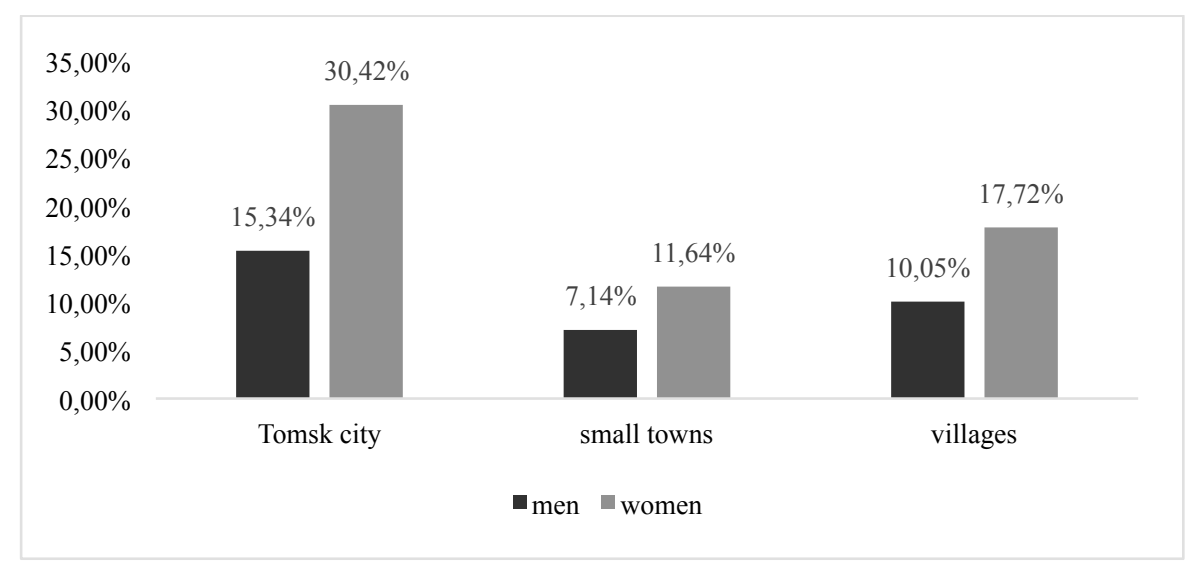

Fig. 2. General life satisfaction in Tomsk region (\% of satisfied with life).

AAI methodology (Active Ageing Index) and data from a survey of the older generation people in Tomsk region, reveal the role of employment domain (as a basis for economic activity) and the role of a participation in society domain (as the composite index of social activity) in the overall level of the older generation activity. The contribution of socio-economic activity in the process of a successful active ageing in Russia is only $25 \%$. The remaining three-quarters of active ageing and independent living and enabling environment, creating opportunities for older persons for having access to the infrastructure, services and physical activity.

\section{Conclusion}

On the basis of Tomsk survey we attempted to identify significant factors of social and economic conditions that affect the behavior of the older generation. They include: economic factors, factors of health and physical activity, social and psycho-emotional condition. Research hypotheses on interdependence between general life satisfaction and satisfaction with specific aspects of life as a whole has been confirmed. Thus, from a practical point of view, promoting favorable conditions for older people in any sphere of life - employment, opportunities to participate in public life, improving the accessibility of the environment, improvement of living conditions - contributes to the total satisfaction, the high level of which, in turn, can compensate for the lack of satisfaction by certain deficient aspects of life.

\section{Acknowledgements}

This work was performed by the authors in collaboration with Tomsk Polytechnic University within the project in Evaluation and enhancement of social, economic and emotional wellbeing of older adults under the Agreement No.14.Z.50.31.0029. 


\section{References}

Elder generation. (2015, June 8). Retrieved from http://www.gks.ru/wps/wcm/connect/rosstat_main/rosstat/ru/ statistics/population/generation/\#

Frolova E., \& Malanina V. (2016). The Foundations of Human Pro-Social Behaviour: Some Economic Aspects. The European Proceedings of Social \& Behavioural Sciences (EpSBS). 7, 424-431. doi: 10.15405/epsbs.2016.02.54

Kolev, A., \& Pascal, A. (2002). What keeps pensioners at work in Russia? Evidence from Household Panel Data. The Economics of Transition. 10(1), 29-53.

Press release \# 2978. (2015, November 19). Retrieved from http://wciom.ru/index.php?id=236\&uid=115470

Taran E., Anikina E., \& Ivankina L. (2016). The Influence of Financial Resources on Later Live. The European Proceedings of Social \& Behavioural Sciences (EpSBS). 7, 461-465. doi: 10.15405/epsbs.2016.02.59

Tchernina N. \& Tchernin E. (2002). Older people in Russia's transitional society: multiple deprivation and coping responses. Ageing and society, 22, 543-562.

Zaidi, A., \& Stanton, .D. (2015). Active Ageing Index 2014: Analytical Report. Retrieved from http://www1.unece.org/stat/platform/download/attachments/76287849/AAI\%20Report\%20LOW\%20RES.PD F? version $=2 \&$ modificationDate $=1433927681725 \&$ api $=\mathrm{v} 2$

Zaidi, A., Gasior, K., Hofmarcher, M.M., Lelkes, O., Marin, B., Rodrigues, R., Schmidt, A., Vanhuysse, P. \& Zolyomi, E. (2013). Active Ageing Index 2012. Concept, Methodology, and Final Results. Research Memorandum. Retrieved from http://www.euro.centre.org/data/aai/1253897823_70974.pdf 